\title{
The Relationship between Hypomagnesaemia and Glycemic Control in Children with Type 1 Diabetes Mellitus
}

\author{
Moustafa N Asmaa ${ }^{1 *}$, Sayed Z Samira ${ }^{1}$, Monir M Aliaa ${ }^{2}$ and Hennes G Bassem ${ }^{2}$ \\ ${ }^{1}$ Department of Pediatrics, Minia University Hospital, El- Minia, Egypt \\ ${ }^{2}$ Department of Clinical Pathology, Minia University Hospital, El- Minia, Egypt
}

*Corresponding author: Moustafa N Asmaa, Faculty of Medicine, Minia University Hospital, 61111, Egypt, Tel: 01005357095; E-mail: Asmaa.reyad@live.com

Received date: Jul 16, 2016; Accepted date: Aug 04, 2016; Published date: Aug 10, 2016

Copyright: ( 2016 Asmaa MN, et al. This is an open-access article distributed under the terms of the Creative Commons Attribution License, which permits unrestricted use, distribution, and reproduction in any medium, provided the original author and source are credited.

\begin{abstract}
Background: Hypomagnesaemia is common in adult patients with both Type 1 Diabetes Mellitus (T1DM) and Type 2 Diabetes MellitusT2DM, especially in poorlycontrolled and chronically treated adults. However, to our knowledge, little research has addressed the relationship between serum magnesium levels and diabetes in children. The aim of the present study was to evaluate magnesium levels and examine their possible association with glycemic control in children with T1DM.
\end{abstract}

Methods: In all, 150 children with T1DM aged between 2 and 16 years and 100 apparently healthy children aged between 2.5 and 16 years were recruited to the study. Using a cross-sectional design, we measured anthropometric parameters, HbA1c, serum magnesium, serum calcium, phosphorus, potassium, sodium, and urinary albumin (UA). Estimated glomerular filtration rate (eGFR), based on serum creatinine concentrations was also calculated.

Results: Lower levels of magnesium were found in subjects with poor versus good glycemic control $(0.81 \pm 0.23$ vs $0.96 \pm 0.19 \mathrm{mmol} / \mathrm{L}$, respectively; $P=0.001)$. Serum magnesium levels were negatively correlated with $\mathrm{HbA} 1 \mathrm{c}(\mathrm{P}$ $=0.002$ ).

Conclusions: The present study shows that serum magnesium levels were lowered in children and adolescents with T1DM and that low serum magnesium levels were associated with an increased risk of poor glycemic control, potentially contributing to the early development of diabetic complications.

Keywords: Children; Glycemic control; Hypomagnesemia; Magnesium; Type 1 diabetes mellitus

\section{Introduction}

Type 1 diabetes mellitus (DM) is a multisystem disease with both biochemical and anatomic/structural consequences. It is a chronic disease of carbohydrate, fat, and protein metabolism caused by the lack of insulin, which results from the marked and progressive inability of the pancreas to secrete insulin because of autoimmune destruction of the beta cells [1].

Hypomagnesaemia is a frequent electrolyte disorder in diabetic patients [2].

$\mathrm{Mg}^{2+}$ is essential for life being involved in numerous enzymatic reactions, including ATP use, cell membrane, ion channels and mitochondrial function, as well as protein synthesis. The most clinically significant consequences of hypomagnesemia are ascribed to alterations in the function of excitable membranes in nerve, muscle, and the cardiac conducting system. Moreover, low serum $\mathrm{Mg}^{2+}$ levels can secondarily induce hypokalemia, hypocalcemia, and hypophosphatemia, potentially causing further derangements in neuromuscular and cardiovascular physiology. Hypomagnesaemia has been implicated in various long-term complications of DM, such as hypertension, increased carotid wall thickness, coronary artery disease, dyslipidemia, diabetic retinopathy, neuropathy, ischemic stroke, and foot ulcerations [2]. Hypomagnesaemia has also been linked to diabetic nephropathy (from microalbuminuria to advanced renal disease) [3]. It has been proposed that hypomagnesaemia is a predictor of end-stage renal disease in patients with diabetic nephropathy [3]. In addition, magnesium deficit is associated with carbohydrate intolerance and insulin resistance, thus inducing or worsening existing $\mathrm{DM}$ [4]. On the contrary, increased dietary $\mathrm{Mg}^{2+}$ intake has been associated with a reduced risk of type $2 \mathrm{DM}$ [5]. Although most studies have demonstrated lower magnesium concentrations in youngsters with T1DM, data concerning the association between magnesium and glycemic control remains obscure. In the present study, we measured serum magnesium levels, along with levels of other electrolytes, in children and adolescents with T1DM to investigate the possible involvement in the glycemic regulation of diabetes in childhood.

\section{Methods}

\section{Study design and subjects}

In all, 150 children with T1DM aged between 2 and 16 years (74 boys, 76 girls) who were followed-up in pediatric endocrinology outpatient's clinic of Minia University Hospital of Children and 100 apparently healthy children ( 50 boys, 50 girls ). All diabetic subjects were treated with insulin given multiple daily injections and were included in the study if they were $<16$ years of age and had a duration of diabetes $>3$ months. 
Citation: Asmaa MN, Samira SZ, Aliaa MM, Bassem HG (2016) The Relationship between Hypomagnesaemia and Glycemic Control in Children with Type 1 Diabetes Mellitus. J Diabetes Metab 7: 693. doi:10.4172/2155-6156.1000693

Page 2 of 5

Exclusion criteria included the presence of acute disease or chronic conditions that could influence magnesium homeostasis. In addition, none of the children had hypertension, diabetic retinopathy, or nephropathy. Informed written consent was also obtained from the parents and/or guardians of all the study subjects who underwent clinically and laboratory investigations.

\section{Data collection}

Weight and height were measured (in $\mathrm{kg}$ and $\mathrm{m}$, respectively) and body mass index (BMI) was calculated as weight divided by height squared. All subjects underwent complete physical examination. After overnight fasting, blood samples were collected from all subjects for measurement of serum levels of magnesium, phosphorus, calcium, potassium, sodium, and creatinine using standard methods. Estimated glomerular filtration rate (eGFR), based on serum creatinine concentrations was calculated using the updated Schwartz formula. In addition, we collected data on total daily magnesium intake by all subjects. Glycemic control was estimated for each patient through HbAlc, measured by HPLC. In addition, each subject gave a random morning urine specimen for the determination of urinary albumin (UA).

\section{Groups and definition of cut-off points}

To define "glycemic control", we used standard international criteria. Based on HbAlc levels, subjects were divided into two groups: (i) Those with good glycemic control (normoglycemic group), defined as HbAlc levels $\leq 7.5 \%$; and (ii) Those with poor glycemic control, defined as $\mathrm{HbA} 1 \mathrm{c}$ levels $>7.5 \%$. Moreover, to examine the association between demographics, clinical or laboratory measurements, and magnesium, subjects were divided into three groups (tertiles) based on magnesium serum concentrations as follows: tertile T1, serum magnesium $<0.75 \mathrm{mmol} / \mathrm{L}$; T2, serum magnesium between 0.75 and $1.03 \mathrm{mmol} / \mathrm{L}$; T3, serum magnesium $>1.03 \mathrm{mmol} / \mathrm{L}$.

\section{Statistical analysis}

The collected data were coded, tabulated, and statistically analyzed using SPSS program (Statistical Package for Social Sciences) software version 20.

Descriptive statistics were done for numerical data by mean, standard deviation, and minimum\& maximum of the range, while they were done for categorical data by number and percentage. Analytical analysis was done for quantitative variables using t-test in cases of two groups with parametric data and Mann -Whitney $U$ in cases of two groups with non-parametric, while correlations were done using Spearman Correlation for non- parametric data. Analytical analyses were done for qualitative data using Chi -square test for cases more than 5 in the variable, and Fisher's exact test for cases less than 5 in the variable.

The level of significance was taken at $\mathrm{P}$ value $<0.050$.

\section{Baseline data}

The mean age of the studied groups were $10.79 \pm 4.36$ years for diabetics and $10.33 \pm 3.15$ for the control group (Table 1). Serum magnesium levels of subjects varied from $0.49-1.77 \mathrm{mmol} / \mathrm{L}$, with a mean value of $0.88 \pm 0.22 \mathrm{mmol} / \mathrm{L}$ in diabetics and $0.74-1.19$, with a mean value of $0.95 \pm 0.09$ in control group $(\mathrm{P}=0.001)$.

\begin{tabular}{|c|c|c|c|}
\hline & $\begin{array}{l}\text { Diabetic group } \\
(n=150)\end{array}$ & $\begin{array}{l}\text { Control group } \\
(n=100)\end{array}$ & $P$ value \\
\hline $\begin{array}{l}\text { Age (years): } \\
\text { Range } \\
\text { Mean } \pm \text { SD }\end{array}$ & $\begin{array}{l}(2-16) \\
10.79 \pm 4.36\end{array}$ & $\begin{array}{l}(2.5-16) \\
10.33 \pm 3.15\end{array}$ & 0.358 \\
\hline $\begin{array}{l}\text { Sex: } \\
\text { Male. } \\
\text { Female. }\end{array}$ & $\begin{array}{l}74(49.3 \%) \\
76(50.7 \%)\end{array}$ & $\begin{array}{l}50(50 \%) \\
50(50 \%)\end{array}$ & 0.918 \\
\hline $\begin{array}{l}\text { Wt }(\mathrm{kg}) \text { : } \\
\text { Range } \\
\text { Mean } \pm \mathrm{SD}\end{array}$ & $\begin{array}{l}(8-70) \\
35.9 \pm 17.33\end{array}$ & $\begin{array}{l}(12-65) \\
31.36 \pm 13.16\end{array}$ & $0.020^{*}$ \\
\hline $\begin{array}{l}\mathrm{Ht}(\mathrm{m}): \\
\text { Range } \\
\text { Mean } \pm \mathrm{SD}\end{array}$ & $\begin{array}{l}(0.78-1.7) \\
1.33 \pm 0.24\end{array}$ & $\begin{array}{l}(0.83-1.7) \\
1.28 \pm 0.19\end{array}$ & 0.108 \\
\hline $\begin{array}{l}\mathrm{BMI}\left(\mathrm{kg} / \mathrm{m}^{2}\right) \text { : } \\
\text { Range } \\
\text { Mean } \pm \mathrm{SD}\end{array}$ & $\begin{array}{l}(13.13-27.28) \\
18.81 \pm 4.19\end{array}$ & $\begin{array}{l}(13.02-23.56) \\
17.84 \pm 2.86\end{array}$ & $0.032^{*}$ \\
\hline
\end{tabular}

Table 1: Comparison between diabetic and control group as regards demographic data.

\begin{tabular}{|c|c|c|c|}
\hline & $\begin{array}{l}\text { Diabetic group } \\
(n=150)\end{array}$ & $\begin{array}{l}\text { Control group } \\
(n=100)\end{array}$ & $P$ value \\
\hline $\begin{array}{l}\mathrm{Mg}^{2+}: \text { Range } \\
\text { Mean } \pm \mathrm{SD}\end{array}$ & $\begin{array}{l}(0.49-1.77) \\
0.88 \pm 0.22\end{array}$ & $\begin{array}{l}(0.74-1.19) \\
0.95 \pm 0.09\end{array}$ & $0.001^{*}$ \\
\hline $\begin{array}{l}\mathrm{Mg}^{2+}: \\
<0.75 \\
0.75-1.03 \\
>1.03\end{array}$ & $\begin{array}{l}56(37.3 \%) \\
68(45.3 \%) \\
26(17.3 \%)\end{array}$ & $\begin{array}{l}2(2 \%) \\
84(84 \%) \\
14(14 \%)\end{array}$ & $<0.001^{*}$ \\
\hline $\begin{array}{l}\mathrm{Ph}^{2+}: \\
\text { Range } \\
\text { Mean } \pm \mathrm{SD}\end{array}$ & $\begin{array}{l}(0.65-2.29) \\
1.55 \pm 0.3\end{array}$ & $\begin{array}{l}(1.03-1.75) \\
1.42 \pm 0.16\end{array}$ & $<0.001^{*}$ \\
\hline $\begin{array}{l}\mathrm{Ca}^{2+}: \\
\text { Range } \\
\text { Mean } \pm \mathrm{SD}\end{array}$ & $\begin{array}{l}(0.59-1.37) \\
1.14 \pm 0.13\end{array}$ & $\begin{array}{l}(1.02-1.9) \\
1.19 \pm 0.13\end{array}$ & $0.002^{*}$ \\
\hline $\begin{array}{l}\mathrm{Na}^{+}: \\
\text {Range } \\
\text { Mean } \pm \mathrm{SD}\end{array}$ & $\begin{array}{l}(124-144) \\
135.22 \pm 4.16\end{array}$ & $\begin{array}{l}(133-143) \\
137.64 \pm 2.34\end{array}$ & $<0.001^{*}$ \\
\hline $\begin{array}{l}\mathrm{K}^{+}: \\
\text {Range } \\
\text { Mean } \pm \mathrm{SD}\end{array}$ & $\begin{array}{l}(2.6-5.1) \\
4.09 \pm 0.63\end{array}$ & $\begin{array}{l}(3.4-5) \\
4.19 \pm 0.42\end{array}$ & 0.159 \\
\hline \multicolumn{4}{|c|}{$\begin{array}{l}\mathrm{Mg}^{2+}: \text { Magnesium; } \mathrm{Ph}^{2+}: \text { Phosphorus; } \mathrm{Ca}^{2+}: \text { Calcium; } \mathrm{Na}^{+} \text {: Sodium; } \mathrm{K}^{+} \\
\text {Potassium }\end{array}$} \\
\hline
\end{tabular}

Table 2: Comparison between diabetic and control group as regarding laboratory parameters. 
Citation: Asmaa MN, Samira SZ, Aliaa MM, Bassem HG (2016) The Relationship between Hypomagnesaemia and Glycemic Control in Children with Type 1 Diabetes Mellitus. J Diabetes Metab 7: 693. doi:10.4172/2155-6156.1000693

Page 3 of 5

Serum phosphorus levels varied from $0.65-2.29 \mathrm{mmol} / \mathrm{L}$, with a mean value $1.55 \pm 0.3$ in diabetics and $1.03-1.75 \mathrm{mmol} / \mathrm{L}$, with a mean value of $1.42 \pm 0.16$ in control group $(\mathrm{P}=0.001)$. Serum sodium levels varied from $124-144 \mathrm{mmol} / \mathrm{L}$, with a mean value $135.22 \pm 4.16$ in diabetics and $133-143 \mathrm{mmol} / \mathrm{L}$, with a mean value of $137.64 \pm 2.34 \mathrm{in}$ control group $(\mathrm{p}<0.001)$ (Table 2$)$.

\section{Analyses of groups with different glycemic control}

Of the diabetic group, $53.3 \%$ of subjects were deemed to have poor glycemic control $(\mathrm{n}=80)$.

\begin{tabular}{|c|c|c|c|}
\hline & \multicolumn{2}{|l|}{ HbA1c } & \multirow{3}{*}{$\begin{array}{l}\mathbf{P} \text { value } \\
\\
0.689\end{array}$} \\
\hline & $\begin{array}{l}\leq 7.5 \\
(n=70)\end{array}$ & $\begin{array}{l}>7.5 \\
(n=80)\end{array}$ & \\
\hline $\begin{array}{l}\text { \#Urinary microalbumin }(\mu \mathrm{g} / \mathrm{ml}) \text { : } \\
\text { Range } \\
\text { Mean } \pm \mathrm{SD}\end{array}$ & $\begin{array}{l}(3-198) \\
35.71 \pm 36.75\end{array}$ & $\begin{array}{l}(4-261) \\
45.21 \pm 57\end{array}$ & \\
\hline $\begin{array}{l}\text { Creatinine }(\mathrm{mg} / \mathrm{dl}) \text { : } \\
\text { Range } \\
\text { Mean } \pm \text { SD }\end{array}$ & $\begin{array}{l}(0.46-1.1) \\
0.66 \pm 0.16\end{array}$ & $\begin{array}{l}(0.46-1.2) \\
0.71 \pm 0.19\end{array}$ & 0.191 \\
\hline $\begin{array}{l}\text { eGFR }\left(\mathrm{mL} / \mathrm{min} \text { per } 1.73 \mathrm{~m}^{2}\right) \text { : } \\
\text { Range } \\
\text { Mean } \pm \mathrm{SD}\end{array}$ & $\begin{array}{l}(78.75-198.14) \\
129.02 \pm 31.43\end{array}$ & $\begin{array}{l}(72.37-224) \\
121.64 \pm 35.13\end{array}$ & 0.180 \\
\hline $\begin{array}{l}\mathrm{Mg}^{2+}(\mathrm{mmol} / \mathrm{L}): \\
\text { Range } \\
\text { Mean } \pm \mathrm{SD}\end{array}$ & $\begin{array}{l}(0.74-1.6) \\
0.96 \pm 0.19\end{array}$ & $\begin{array}{l}(0.49-1.77) \\
0.81 \pm 0.23\end{array}$ & $<0.001^{\star}$ \\
\hline $\begin{array}{l}\mathrm{Ph}^{2+}(\mathrm{mmol} / \mathrm{L}): \\
\text { Range } \\
\text { Mean } \pm \mathrm{SD}\end{array}$ & $\begin{array}{l}(1.16-2.26) \\
1.53 \pm 0.22\end{array}$ & $\begin{array}{l}(0.65-2.29) \\
1.56 \pm 0.36\end{array}$ & 0.488 \\
\hline $\begin{array}{l}\mathrm{Ca}^{2+}(\mathrm{mmol} / \mathrm{L}): \\
\text { Range } \\
\text { Mean } \pm \mathrm{SD}\end{array}$ & $\begin{array}{l}(0.59-1.37) \\
1.17 \pm 0.13\end{array}$ & $\begin{array}{l}(0.69-1.32) \\
1.11 \pm 0.12\end{array}$ & $0.003^{*}$ \\
\hline $\begin{array}{l}\mathrm{Na}^{+}(\mathrm{mmol} / \mathrm{L}): \\
\text { Range } \\
\text { Mean } \pm \mathrm{SD}\end{array}$ & $\begin{array}{l}(127-144) \\
136.08 \pm 4.14\end{array}$ & $\begin{array}{l}(124-142) \\
134.47 \pm 4.05\end{array}$ & $0.018^{*}$ \\
\hline $\begin{array}{l}\mathrm{K}^{+}(\mathrm{mmol} / \mathrm{L}) \\
\text { Range } \\
\text { Mean } \pm \mathrm{SD}\end{array}$ & $\begin{array}{l}(3.3-5.1) \\
4.14 \pm 0.5\end{array}$ & $\begin{array}{l}(2.6-5) \\
4.05 \pm 0.73\end{array}$ & 0.401 \\
\hline
\end{tabular}

Table 3: Comparison between those with poor and good glycemic control as regarding laboratory data.

As shown in Table 3, serum magnesium and calcium levels were significantly lower in the subgroup with poor glycemic control compared with the subgroup with good glycemic control. In contrast, no significant differences in potassium and phosphorus levels were observed between these two subgroups.

\section{Correlation analysis between serum magnesium levels and other biochemical parameters in the diabetic children}

As shown in Table 4 there were negative correlation between serum magnesium and $\mathrm{HbAlc}(\mathrm{r}=-0.246 ; \mathrm{p}=0.002)$ and positive correlation between serum magnesium and serum phosphorus $(r=0.238 ; p=0.003)$. There is no significant correlation between magnesium and other parameters.

\begin{tabular}{|l|l|l|}
\hline \multirow{2}{*}{ Diabetic group } & $M^{2+}$ & P value \\
\cline { 2 - 3 } & r & 0.228 \\
\hline Age (years) & 0.099 & 0.911 \\
\hline BMl (kg/m²) & 0.009 & 0.251 \\
\hline Duration of DM (years) & 0.094 & $0.040^{*}$ \\
\hline Urinary Microalbumin $(\mu \mathrm{g} / \mathrm{dl})$ & -0.168 & 0.320 \\
\hline Creatinine (mg/dl) & -0.085 & $0.040^{*}$ \\
\hline eGFR (mL/min per 1.73 $\left.{ }^{2}\right)$ & 0.168 & $0.002^{*}$ \\
\hline $\mathrm{HbA}^{2} \mathrm{c}(\%)$ & -0.246 & $0.003^{*}$ \\
\hline $\mathrm{Ph}^{2+}(\mathrm{mmol} / \mathrm{dl})$ & 0.238 & 0.096 \\
\hline $\mathrm{Ca}^{2+}(\mathrm{mmol} / \mathrm{dl})$ & 0.136 & 0.673 \\
\hline $\mathrm{Na}^{+}(\mathrm{mmol} / \mathrm{dl})$ & 0.035 & 0.189 \\
\hline $\mathrm{K}^{+}(\mathrm{mmol} / \mathrm{dl})$ & 0.108 & \\
\hline
\end{tabular}

Table 4: Correlation between serum magnesium and the other parameters in diabetic group.

\section{Discussion}

In the present study, we measured serum magnesium levels, as well as other clinical and biochemical parameters, in children with T1DM. The aim of the present study is to investigate the frequency of hypomagnesaemia and also to identify the correlation between serum magnesium and other parameters as the degree of glycemic control.

In the present study, there were 56 subjects $(37.3 \%$ of the diabetic sample) who had hypomagnesaemia.

This result is in agreement with many studies as [6]. who made a Comparative study on magnesium in diabetic and non-diabetic patients and found a significant fall of serum magnesium in patients with diabetes [6] and Pham et al. [7] who studied lower serum magnesium levels association with more rapid decline of renal function in patients with diabetes mellitus and also reported hypomagnesaemia in $47.7 \%$ of non-hospitalized patients with diabetes mellitus $[7,8]$ studied the trace mineral status related to levels of glycated hemoglobin of diabetic subjects, and explained the hypomagnesaemia that associated with diabetes mellitus by osmotic diuresis which is the cause for magnesium loss. It is believed that glycosuria that accompanies the diabetic state impairs renal tubular reabsorption of magnesium from glomerular filtrate. Conversely, insulin deficiency may explain the increased urinary magnesium excretion, because insulin has been recognized to stimulate magnesium conservation in the loop of Henle and distal tubule [8]. Moreover, uncontrolled hyperglycemia and hyperglycuria may 
increase magnesium excretion through osmotic diuresis, leading to a vicious circle [9].

What strengthens this view is that hypomagnesaemia in diabetes often coexists with other electrolyte disorders [10]. In contrast to these results, [11] who study serum Zinc and Magnesium levels in diabetic patients and showed that there was no significant difference between serum magnesium levels in both cases and control groups. This may be explained by the small sample size of diabetic patients in this study [11].

Although there is a lack of agreement regarding the cause of lower magnesium levels in diabetes, it has been suggested that inadequate magnesium intake, hypermagnesuria, or gastrointestinal disorders could be reasonable explanations. In addition, it has been reported that young subjects with T1DM consume significantly more magnesium than those with T2DM [12].

Indeed, another finding of the present study was a significant statistical reduction of serum sodium level in diabetic group compared with control group $(\mathrm{p}<0.001)$ was observed in parallel with the reduction in magnesium levels.

There was also a statistically significant reduction of serum calcium in the poorly controlled group compared with good control one $(\mathrm{p}=0.003)$

These results supported by Cristi urienk [13] who studied hypomagnesaemia in type 1 diabetes and found that hypomagnesemia in diabetes often coexists with other electrolyte disorders as hyponatraemia and hypocalcaemia [13].

This is explained by cellular magnesium deficiency can alter the activity of membrane-bound sodium-potassium ATPase that is involved in the maintenance of gradients of sodium, potassium and in glucose transport and can also be explained by the osmotic diuresis caused by uncontrolled hyperglycemia and hyperglycuria that increase urinary excretion of sodium and calcium [9].

In the current study, we found a significant negative correlation between serum magnesium and HbA1c levels $(r=-0.246 ; p=0.002)$. Our study revealed that uncontrolled diabetic patients are at higher risk of hypomagnesaemia.

This result is supported by shaikh [14]. who studied hypomagnesaemia in diabetic patients and found significantly negative correlation between $\mathrm{HbAlc}$ levels and serum magnesium Shaikh, Kundu et al. $[14,15]$ studied serum magnesium levels in patients with diabetic retinopathy and reported that there was a negative correlation between magnesium level and HbAlc level $[13,15]$ study that was performed upon 138 type 1 diabetic children and adolescents also reported that there was a negative correlation between magnesium level and $\mathrm{HbA} 1 \mathrm{c}$ level $(\mathrm{r}=-0.317 ; \mathrm{P}<0.001)$ [13].

This negative correlation between serum magnesium and $\mathrm{HbAlc}$ is explained by the affection of hyperglycemia on magnesium excretion as uncontrolled hyperglycemia and hyperglycuria may increase magnesium excretion through osmotic diuresis [13].

However, in contrast to our study [15] who studied Ionized magnesium in Danish children with type 1 diabetes and stated that plasma magnesium was not correlated with glycaemic control as measured by HbAlc [16]. This is possibly because of good glycemic regulation or the small number of participants in this study.
The role of magnesium administration in glycemic control remains controversial [17] it has been shown that oral or intravenous supplementation of magnesium in T1DM patients results in increased levels of magnesium in erythrocytes or skeletal muscle and decreased insulin requirements, but has no effect on metabolic control.

It could be demonstrated that there is a relationship between hypomagnesaemia and the late diabetic complications and this evidence shows the concept of evaluating magnesium levels in serum of diabetic patients particularly with poor glycemic control [18].

The relationship between metabolic control and impaired magnesium balance was corroborated when studies showed that insulin-treated T2DM or T1DM patients with severe background or proliferative retinopathy demonstrated lower serum magnesium levels than those with no or mild background retinopathy [19].

Sharma et al. [19] concluded that serum magnesium has also been shown to be lower in T1DM patients with polyneuropathy, and magnesium supplementation has been reported to improve nerve conduction and reduce the incidence of polyneuropathy, at least in young patients with a short duration of diabetes and early neurological signs [20].

Recently, a significant inverse association was found between serum magnesium concentrations and risk of total cardiovascular events [21]. whereas low serum magnesium levels have been shown previously to predict cardiovascular and all-cause mortality in a population-based study during follow-up as well [22].

Moreover, serum magnesium levels have been inversely and independently associated with the intima-media thickness of common carotid artery in adolescents with type 1 diabetes mellitus (T1DM), which is a well-accepted early marker of atherosclerosis [23]

Together, these data suggest that hypomagnesaemia may be an important risk factor for the development of diabetic micro- and macrovascular disease.

\section{Conclusion}

In conclusion, the present study has shown that low serum magnesium levels in children with T1DM are associated with an increased risk of poor glycemic control, potentially contributing to the early development of diabetic complications. These data indicate that the relationship between magnesium status and diabetes control begins in childhood. Intervention studies are needed to further elucidate whether restoration of magnesium balance, through the consumption of foods with a high magnesium content, or even via medication, could improve disease control and prevent potential longitudinal complications.

\section{Conflict of Interest}

We declare no conflict of interest.

\section{Acknowledgement}

We have not received any funding from any corporate body or pharmaceutical company. 
Citation: Asmaa MN, Samira SZ, Aliaa MM, Bassem HG (2016) The Relationship between Hypomagnesaemia and Glycemic Control in Children with Type 1 Diabetes Mellitus. J Diabetes Metab 7: 693. doi:10.4172/2155-6156.1000693

Page 5 of 5

\section{References}

1. Sergio AD, Marilia BG (2009) Etiopathogenesis of type 1 diabetes mellitus: prognostic factor for evolution of residual $\beta$-cell function. Diabetology and Metabolic syndrome 1: 1-25.

2. Pham PC, Pham PM, Pham SV, Miller JM, Pham PT (2007) Hypomagnesemia in patients with type 2 diabetes. Clin J Am Soc Nephrol 2: 366-373.

3. Sakaguchi Y, Shoji T, Hayashi T, Suzuki A, Shimizu M, et al. (2012) Hypomagnesemia in type 2 diabetic nephropathy: a novel predictor of end-stage renal disease. Diabetes Care 35: 1591-1597.

4. Barbagallo M, Dominguez LJ (2007) Magnesium metabolism in type 2 diabetes mellitus, metabolic syndrome and insulin resistance. Arch Biochem Biophys 458: 40-47.

5. Dong JY, Xun P, He K, Qin LQ (2011) Magnesium intake and risk of type 2 diabetes: meta-analysis of prospective cohort studies. Diabetes Care 34: 2116-2122.

6. Anjum A, Yousaf M, Zuber M, Ahmad HB, Zahoor AF (2012) Comparative study on calcium, magnesium and cobalt in diabetic and non-diabetic patients (males) in Punjab, Pakistan. AJB 11: 7258-7262.

7. Pham PC, Pham PM, Pham PA, Pham SV, Pham HV, et al. (2005) Lower serum magnesium levels are associated with more rapid decline of renal function in patients with diabetes mellitus type 2. Clin. Nephrol 63: 429-436.

8. Farid SM, Abulfaraj TG (2013) Trace mineral status related to levels of glycated haemoglobin of diabetic subjects in Jeddah, Saudi Arabia. Medical Journal of Islamic World Academy of Sciences 21: 47-56.

9. Dai LJ, Ritchie G, Kerstan D, Kang HS, Cole DE, et al. (2001) Magnesium transport in the renal distal convoluted tubule. Physiol Rev 81: 51-84.

10. Iran J (2010) Hypomagnesemia AF. An evidence-based approach to clinical cases. Kidney Dis 4: 13-19.

11. Masood N, Baloch GH, Ghori RA, Memon IA, Anwar, et al. (2009) Serum Zinc and Magnesium in Type 2 Diabetic patients. J Coll Physicians Surg Pak 19: 483-486.

12. Mayer-Davis EJ, Nichols M, Liese AD (2006) Dietary intake among youth with diabetes: The SEARCH for Diabetes in Youth Study. J Am Diet Assoc 106: 689-697.
13. Cristi urienk (2008) National Collaborating Centre for Chronic Conditions UK. Type 2 diabetes.

14. Shaikh MK, Devrajani BR, Soomro AA, Ali Shah SZ, Devrajani T, et al. (2011) Hypomagnesemia in Patients with Diabetes mellitus. World Applied Sciences Journal 12: 1803-1806.

15. Kundu D, Osta M, Mandal T, Bandyopadhyay U, Ray D, et al. (2013) Serum magnesium levels in patients with diabetic retinopathy. J Nat SciBiol Med 4: 113-116.

16. Matthiesen G, Olofsson K, Rudnicki M (2004) Ionized magnesium in Danish children with type 1 diabetes. Diabetes Care 27: 1216-1217.

17. Yeh GY, Eisenberg DM, Kaptchuk TJ, Phillips RS (2003) Systematic review of herbs and dietary supplements for glycemic control in diabetes. Diabetes Care 26: 1277-1294.

18. Muhammed KS, Bikha RD, Aftab AS, Syed Zulfiquar AS, Tarachand D, et al. (2011) Hypomagnesemia in Patients with Diabetes mellitus. World Applied Sciences Journal 12: 1803-1806.

19. Sharma A, Dabla S, Agrawal RP, Barjatya H, Kochar DK, et al. (2007) Serum magnesium: An early predictor of course and complications of diabetes mellitus. J Indian Med Assoc 105: 16-20.

20. De Leeuw I, Engelen E, De Block C, Van Gaal L, christian kurizanta T (2004) Long term magnesium supplementation influences favourably the natural evolution of neuropathy in $\mathrm{Mg}$-depleted type 1 diabetic patients (T1dm). Magnes Res 17: 109-114.

21. Qu X, Jin F, Hao Y (2013) Magnesium and the risk of cardiovascular events: A meta-analysis of prospective cohort studies. PLoS ONE 8: e57720.

22. Reffelmann T, Ittermann T, Dorr M (2011) Low serum magnesium concentrations predict cardiovascular and all-cause mortality. Atherosclerosis 219: 280-284

23. Atabek ME, Kurtoglu S, Pirgon O, Baykara M (2006) Serum magnesium concentrations in type 1 diabetic patients: Relation to early atherosclerosis. Diabetes Res Clin Pract 72: 42-47. 